Waterthrushes and American Redstarts, and some rare species such as Magnolia, B a y-breasted, Blackthroated Blue, and Canada Warblers. Warblers were reported as unusually common in Saskatoon this fall, and Dr. Stuart Houston had a very successful season of banding (see article in this isisue). However, at Fort Qu'Appelle, Manley Callin found only Myrtle Warblers as abundant as usual, with other species fewer in number.

The abundance of warblers and the variety of species represented in the 1965 fall migration makes it seem worthwhile to show arrival and departure dates, with indications of peaks where possible (see Table 3 ). It will be seen in this table that almost all the common migrants had arrived in the area by the end of August, and it will also be noted that a surprisingly large number of species did not leave until October. These late dates are curiously interesting, especially since they represent same of the most striking observations - the Parula Warbler seen by the Binnies from October 21 to 24, the Cape May Warbler seen by Belcher October 21 (previously on September 23 by R. W. Nero, and on October 3 by the Binnies), and of course the Bluewinger Warbler found dead on November 9. The last record we have for the season is that of an unidentified warbler, described as being greenish in colour, with a gray head and white eye-ring, glimpsed briefly by Greg Bobbitt on November 13.

In making this survey, the authors wish especially to acknowledge the work done by Fred Lahrman, who visited the CKCK-TV tower regularly throughout the fall migration and made his notes available for this report.

\section{LITERATURE CITED}

Belcher, Margaret. 1961. Birds of Regina. Spec. Pub. No. 3, Saskatchewan Nat. Hist. Society, Regina.

Binnie, Alvin. 1965. Parula Warbler recorded near Regina. Blue Jay, $23: 170$.

Brazier, Frank. 1965. A Myrtle Warbler nesting record for Regina. Blue Jay, $23: 125-126$.

Lahrman, Fred W. 1962. Fall migration TV tower kills, 1262. Blue Jay, $20: 152$.

Lahrman, Fred W. 1965. Regina and Lumsden TV tower bird mortalities, 1964. Blue Jay, $23: 18$ - 19.

Nero, Robert W. 1961. Regina TV tower bird mortalities - 1961. Blue Jay, $19: 160-164$.

Nero, Robert W. 1962. Regina TV tower mortality May 11-12, 1962. Blue Jay, $20: 151$ 152.

\title{
MIST NETTING AT SASKATOON, AUTUMN 1965
}

\section{by C. Stuart Houston and Mary Houston, Saskatoon}

Mist netting of birds has long been an art in Japan, but it was first popularized on this continent by Oliver $\mathrm{L}$. Austin, Jr., who served with the American troops during the occupation of Japan immediately following the war. Silk or nylon nets, 30 to 60 feet in length and five or six feet high, are strung between poles. The nets are virtually invisible so that birds readily fly into them and pocket themselves unharmed. A special permit is required to operate mist nets.

On five weekends in August and September, 1965,10 to 12 nets were put in place on Saturday evening and attended from dawn to dusk on Sunday, at 15 - to 20 -minute intervals. An excellent sampling of the migration was thus obtained, for example, no less than 17 species of warblers and four species of vireo's were banded, for a total of 190 individuals. With the bird in the hand, one can identify with certainty many species that would be difficult or impossible to identify in the field. Weights and measurements were obtained of all individuals. Members of the Saskatoon Natural History Society who assisted included Jim Slimmon (see photo), J. B. Gollop, Glen A. Fox, Sandy Macaulay, John Black, Cliff Matthew's, Bill Richards, Jonathan Gerrard, Bob Ipema and Stan Houston. 


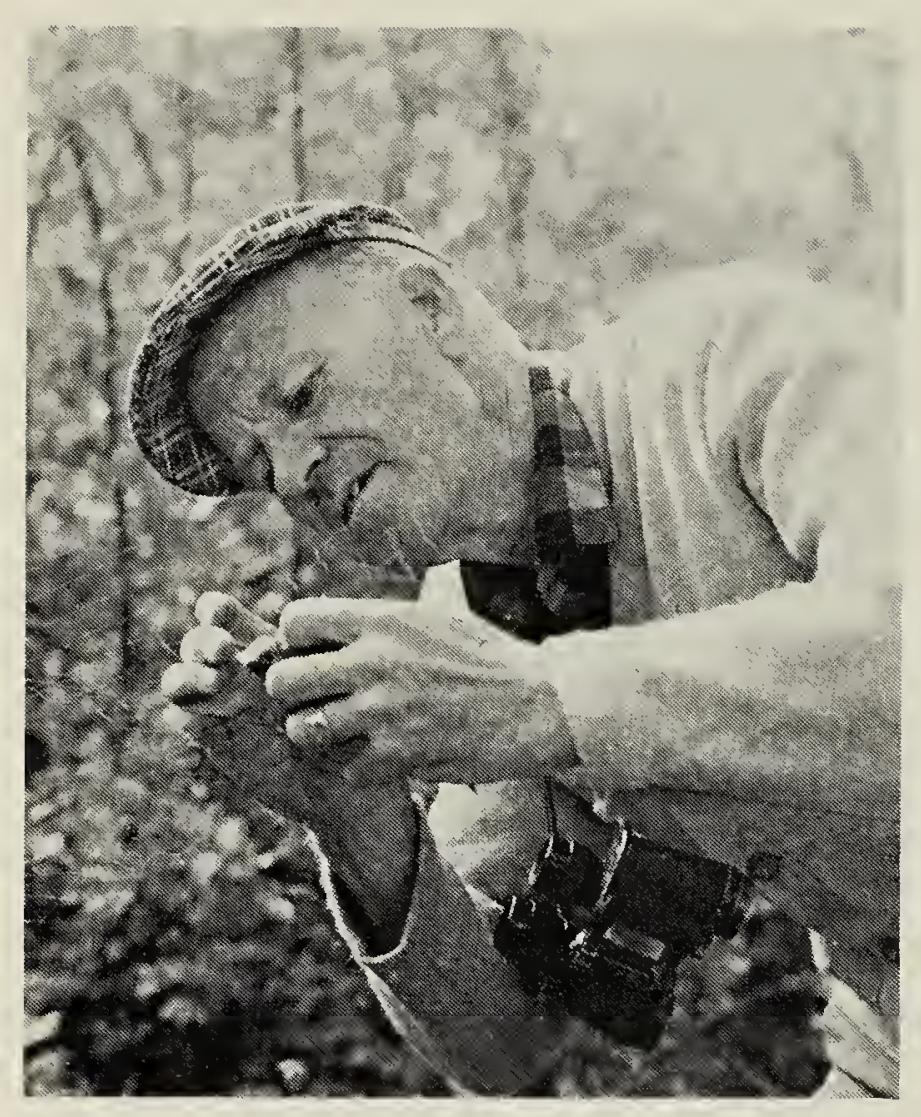

Photo by Hans Dommasch

Jim Slimmon, Newsletter editor and president of the Saskatoon Natural History Society, removing a bird from a mist net.

The accompanying table shows the most interesting of the species which we banded. The wading birds were banded at the north shore of a fourmile long marshy area known locally as "Rice Lake", one mile south of Hawoods, or 11 miles north and one mile east of Delisle. The other birds were netted in the Beaver Creek valley, adjacent to the Game Farm, 10 miles south of Saskatoon. Totals for the weekends were as follows: 136 individuals of eight species on August $21-22 ; 16$ birds of nine species on August $28-29 ; 59$ of 18 species on September $4-5 ; 53$ of 16 species on September 11-12; 115 individuals of 18 species on September 18-19.
TABLE 1

Species of interest trapped in mist nets and banded near

Saskatoon.

No.

Species

Date banded

Semipalmated Plover

Killdeer

Aug. 21-22 13

Aug. 21-22 4

Lesser Yellowlegs

Pectoral Sandpiper

Aug. 21-22 6

Aug. 21-22 13

Least Sandpiper

Aug. 21-22 52

Semipalmated

Sandpiper

Hermit Thrush

Aug. 21-22 46

Swainson's Thrush Aug. 27-Oct. 567

Gray-cheeked Thrush

Aug. 29-Sept. $26 \quad 14$

Ruby-crowned Kinglet

Solitary Vireo

Red-eyed Vireo

Philadelphia Vireo

Warbling Vireo

Black-and-white

Warbler

Tennessee Warbler

Orange-crowned

Warbler

Sept. 18

Sept. 2-12

Sept. 5

Sept. 12

Sept. 5

Sept. $5 \quad 1$

Sept. 2-19 18

Yellow Warbler Aug. 29-Sept.11 5

Magnolia Warbler

Cape May Warbler

Myrtle Warbler

Sept. 192

Sept. 4-19 7

Sept. 5-19 46

Chestnut-sided Warbler Sept. 22

Bay-breasted Warbler Sept.2-5 4

Blackpoll Warbler Sept.2-19 31

Ovenbird Aug.31-Sept.19 17

Northern Water-

thrush

Aug. 25-Sept. 19

24

Mourning Warbler Sept. 161

Yellowthroat Oct. 31

Wilson's Warbler Aug. 31-Sept. 128

Canada Warbler Aug.20-Sept. 12

American

Redstart Aug.29-Sept. 9

8
5
2
7
6
2
4
1
7

4
1
1
8
2

4
6
2

6

4

1

2

1

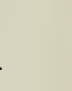

\section{INFORMATION WANTED ON OWL NESTS}

Anyone finding a Great Horned Owl nest with young in April or May anywhere in the province or nearby is asked to please contact Dr. Stuart Houston, 863 University Drive, Saskatoon, or phone collect to 244-0742.

From 385 Great Horned Owls banded to date, Dr. Houston has had 49 recoveries, including two from Minnesota, two from North Dakota, one from South Dakota, and seven from Manitoba. From further banding, it is hoped to learn more about the wanderings of this "nonmigratory" species. 